
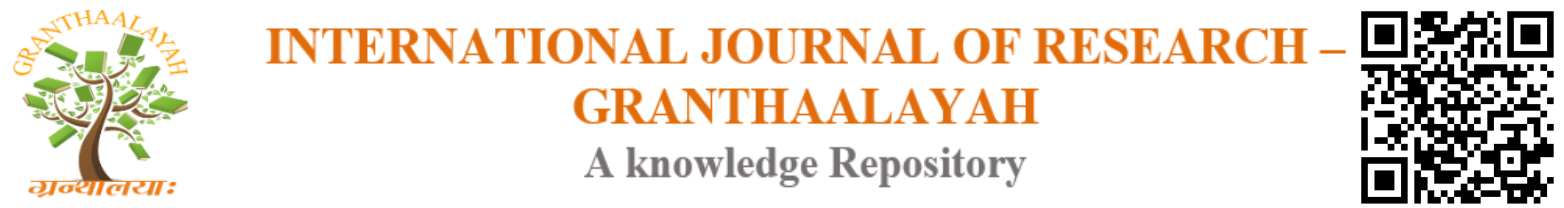

Science

\title{
ANDROID APPLICATION OF MIDDLE-SMALL BUSINESS MAPPING (UKM) IN TEGAL CITY BASED ON GEOGRAPHIC INFORMATION SYSTEM (GIS) AND LOCATION-BASED SERVICE(LBS)
}

\author{
Jatmiko Indriyanto ${ }^{* 1}$, Imam Bukhori ${ }^{2}$, Eko Budihartono ${ }^{3}$ \\ *1, 2, 3 Politeknik Harapan Bersama J1. Mataram Pesurungan Lor Kota Tegal, Indonesia
}

\begin{abstract}
Researchers began to research UKM, Tegal City Cooperative Service and region in Tegal City, researchers found in UKM, a location that has businesses in various places in the village, especially regarding UKM. However, many of these UKM locations are unknown to the public. One problem is the lack of data regarding the address and location of UKM. So now it is very much needed an android application using GIS and LBS that will facilitate and help the people of Tegal to be able to obtain data and find out more about UKM in the city of Tegal. Google Maps is an application on Android smartphones and computers that can be accessed via the internet so that Google Maps can display on Android. The purpose of this study is to facilitate the Tegal community to find information on locations, products, and UKM owners, based on a survey by researchers. The implementation of the UKM location mapping system in the city of Tegal will certainly make it easier for the people of Tegal to find data about the addresses and products of UKM in the city of Tegal. Because every data needed becomes more accurate, fast and efficient.
\end{abstract}

Keywords: UKM; GIS; LBS; Android; Tegal; UKM.

Cite This Article: Jatmiko Indriyanto, Imam Bukhori, and Eko Budihartono. (2019). "ANDROID APPLICATION OF MIDDLE-SMALL BUSINESS MAPPING (UKM) IN TEGAL CITY BASED ON GEOGRAPHIC INFORMATION SYSTEM (GIS) AND LOCATION-BASED SERVICE(LBS)." International Journal of Research - Granthaalayah, 7(9), 172-182. https://doi.org/10.29121/granthaalayah.v7.i9.2019.586.

\section{Introduction}

Information technology is developing in the current era of globalization very quickly. Nowadays information technology has become a necessity and a demand in all aspects of life. Realtime, fast and accurate information needs become very important for the survival of human beings today. Data and information needed must be easily accessed effectively and efficiently by various interested parties. Society needs access to technology is very diverse, one of the desires is the desire for the availability of a data service location for Small and Medium Enterprises (SMEs) based on Android GIS. Micro, Small and Medium Enterprises (MSMEs) require a lot of innovation to continue to improve the product marketing model so that products can be marketed more widely 
and more easily than the existing sales model. One of these ideas is to use marketing technology that can cross national borders easily, namely information and communication technology. Mukhyi (2008), said, "There are currently not many phenomena and there are even many SMEs that have not and do not use information technology assistance". Therefore, it is better for information and communication technology that is developing at this time to be developed in this case as a marketing medium. Therefore, it is necessary to provide information services for Small and Medium Enterprises (SMEs) based on Android GIS and LBS that can be used by the Tegal city community and government agencies. The Tegal City Cooperative Office is one area that has various types of businesses in each district, region, especially regarding Small and Medium Enterprises (UKM). However, these efforts are not widely known by the wider community. One obstacle is the lack of data regarding the location of Small and Medium Enterprises (SMEs) [4]. Therefore, it is very necessary android application using Geographic Information System (GIS) \& Location Based Services (LBS) that will support and facilitate the citizens of the city of Tegal to be able to obtain information and find out more about SMEs in the city of Tegal. Location-Based Services (LBS) \& Geographic Information System (GIS) itself uses facilities from Google Maps [3].

\section{Materials and Methods}

This research software engineering system is very prominent so there needs to be an adjustment. This is in line with what was stated by Martin (2004: 28) which says to build software we must undergo the stages of requirements analysis, design, coding, and testing.

Through collaboration these stages will produce levels of research following the formulation and research objectives, namely:

1) The analysis stage

2) The level of decomposition

3) Development stage

4) Test level

5) Reporting

\section{Analysis Phase}

In the process of designing a product, it is necessary to have a preliminary review that is useful for determining the objectives of the population made. Analysts are needed in planning a product because it will determine the effectiveness and efficiency of a product that will be made. At this level, the researcher makes two approaches, namely with literature studies and field studies. A literature study is carried out for ideas from experts and technology practitioners who play an active role in technological development. While the field study is used by researchers to examine the factual results that are happening in their environment.

\section{Design Stage}

The design stage is an element that includes determining the elements that need to be made in software that will be made according to the learning design (Munir, 2008: 197). The design process of learning software development includes two aspects of design, namely aspects of the ID model (Instructional design) or aspects teaching content to be provided. 


\section{Development Stage}

The stages of development are the steps taken to translate the design results into computer program code. At this stage the flowchart, UML, storyboard and ERD designs are implemented in the PHP computer program code lines. Explains that in the process of developing this production intends to produce the initial product and then be tested or run on a computer to ascertain whether the Android application is following what we want or not [11].

\section{Testing Phase}

In the final development, a test was performed on the role of the android application and the operation was carried out directly to several people from SMEs. In the first stage, the researcher carried out without the other participants. This stage is aimed at whether the application is running well. After the first phase has been completed, the second stage will be tested, namely testing directly to other SMEs who will try the Android-based application [10].

\section{Results and discussions}

\section{Model Framework}

UKM Android application based on GPS and LBS is computer software developed to help people to find the location of SMEs and find out their products. In other words, the UKM Android application based on GPS and LBS is an Android-based software developed by the author himself. The main objective of GPS and lbs based UKM android application is to make it easier for people to find the location of the SME city of Tegal. Specifically, the GPS and lbs based UKM android application is expected to help the public in knowing the products made in UKM in the city of Tegal. In the GPS and lbs based UKM android application, the public is welcome to try the android application on mobile to find the location of the UKM in the city of Tegal.

The UKM and GPS-based UKM Android application was developed using the Android Studio application and a database on hosting that is accessed directly for people who use Android phones. This application allows knowing the location of SMEs, both the distance and time of our position. The following is the initial appearance of the UKM Android application based on GPS and LBS that has been made.

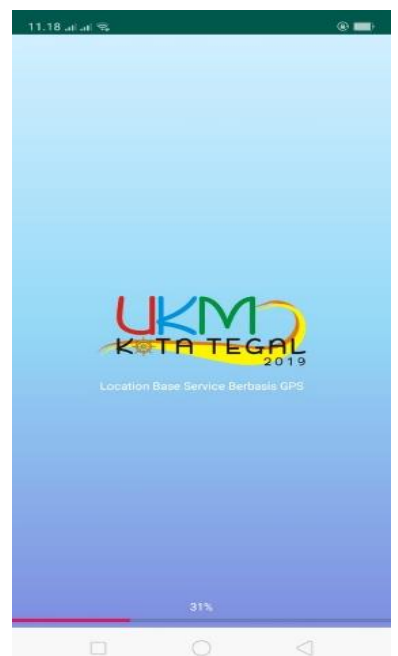

Picture 1: Display Splash screen 


\section{System Analysis}

The understanding of a system is a group of components or elements that work together and relate to achieving a certain goal. The elements of a system consist of input, process, and output. GPS and LBS-based UKM Android Application System which is part of the GPS and LBS-based UKM Android application that is inseparable from the input and output data elements of the system model that unites information system technology to the community. The SME location information online system is the basis of the SME information design analysis, thus the system to be built is based on the SME location online model. In the android application system is an information application that connects the community with the SMEs in the city of Tegal.

\section{System Flow}

The GPS and lbs based UKM android application was developed based on the community's need to search for UKM products, it is often difficult to find it, through this application it is expected to facilitate the search and product information. Meanwhile, the admin (superuser) is the user of the system that provides the product, location, name of the SME owner that is needed by the community, and the use of the system without constraints.

Based on the requirements of the user of the system the following explains the uses of each user entity in the system:

1) Administrators entity: user administrators are internal entities that use the system in terms of delivering services to all users of the application user.

Functions: updating the location of SMEs, updating SMEs products, updating the owner and address of SMEs.

2) Application user entity: application user that is an entity outside of the system that uses the android application directly through their mobile phones.

Function: find the location of SMEs, view km product information, view SME owner information, view SME address information.

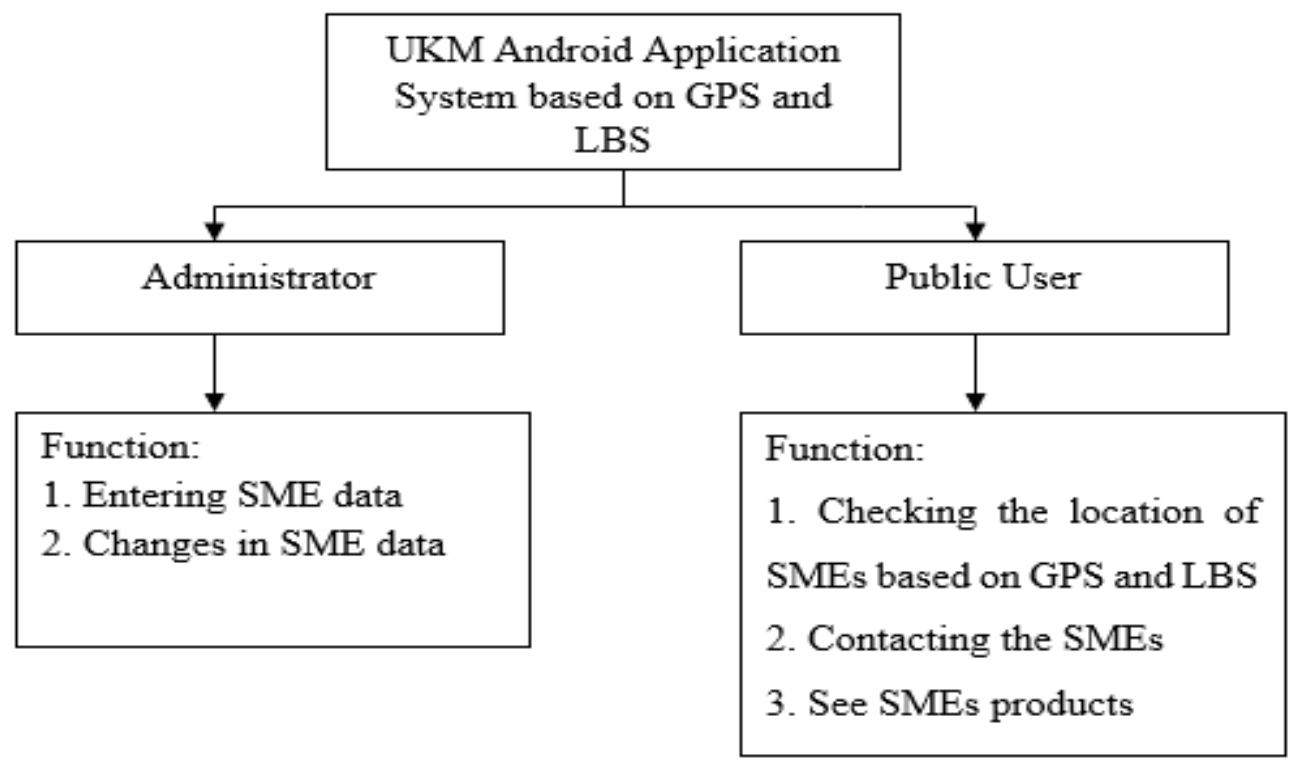

Picture 2: Display the system process flow 
Here is a picture in the GPS and LBS based UKM Android application

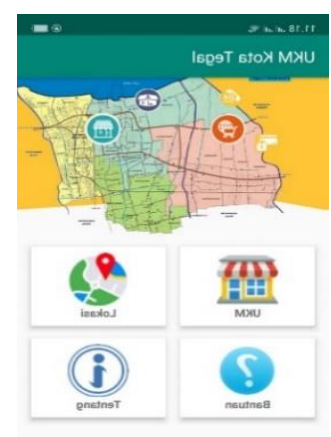

Picture 3: Display Menu

\section{Data Flow Diagrams (DFD)}

Data Flow Diagrams (DFD) are essentially a data logic model or process that is made to describe where the source of data originates, where the destination data comes out of the system and where the data will be stored. In general, DFD is a picture that illustrates the flow of data related to the input, process, and output of the system model [9].

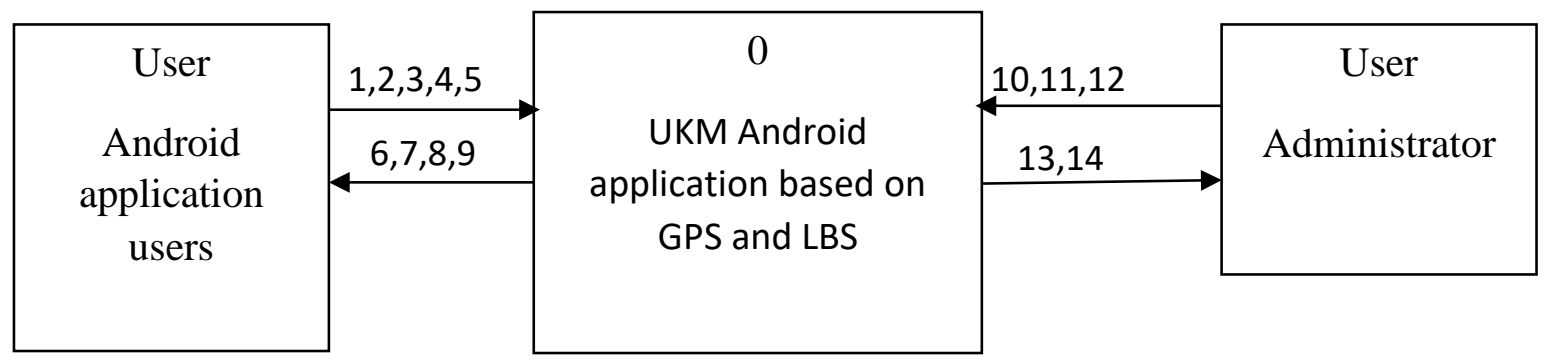

Picture 4: Context Diagram System

Information:

1) Open the application and see the splash screen

2) See the application menu

3) Enter the UKM menu

4) Enter the location menu

5) Enter the help menu

6) Enter the About menu

7) Search for SMEs information in SMEs menu

8) Search for GPS location in the location menu

9) See information on the about menu

10) Change the data of SME owners

11) Changing the SMB address data

12) Change the photo data of SMEs owners

13) Changing GPS location data and lbs UKM

14) Changing photo data of SMEs 
UML (Unified Modeling Language)

UML is a capital standard for object-oriented programming languages. UML is a most likely open standard controlled by an object management group (OMG). Reverse engineering is the stage of making UML from the program code created.

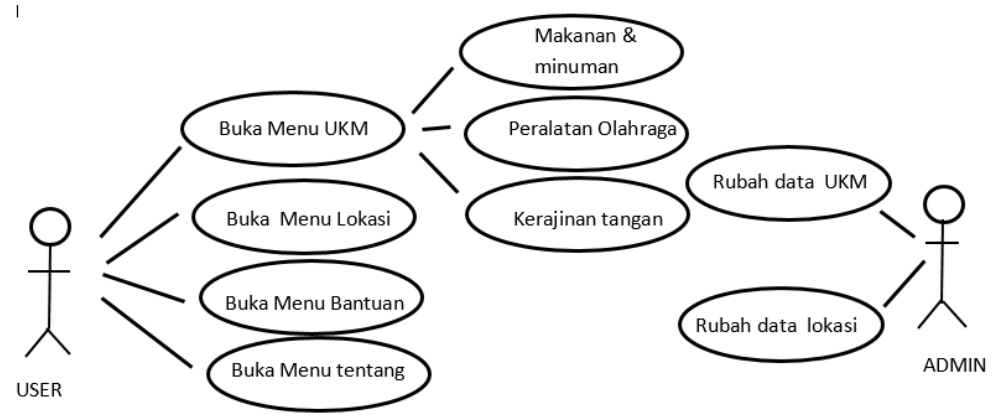

Picture 5: Diagram UML

\section{Development Research Data in the Field}

a. Data on Application Development for Android UKM based on GPS and LBS

The first research result is the compilation of GPS and lbs based android application which contains location information, products, and address of funds that can be used by the community. The development of instructional media was first begun with an introductory stage which included gathering information about problems that arise during the application use process. Data from the initial stage of information gathering becomes a guideline for researchers to conduct a needs analysis in the use of application activities and to compile the making of applications which will be further developed. The information is about how the implementation of GPS and lbs-based UKM android applications carried out by the community monitored by the admin.

In the second stage, the planning stage includes determining the purpose of making GPS and lbs based android applications. The development of GPS and lbs-based UKM android applications are aimed at making the initial process of using android applications by the public accustomed to using an android mobile phone so that it will facilitate the community when using the application.

from the results of this development, the following are the results of the display of the application program for Android SMEs based on GPS and LBS.

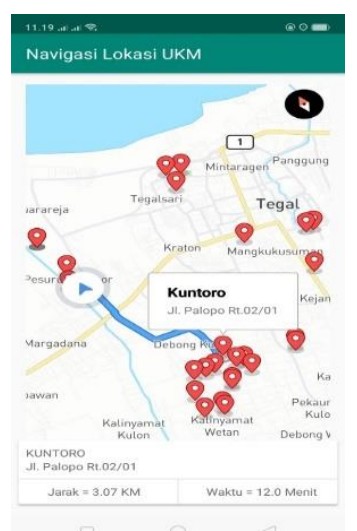

Picture 6: GPS location and LBS SMEs 
b. The Feasibility Assessment Results of the UKM Android application based on GPS and LBS The following are the results of the appraisal results of GPS and LBS based UKM Android applications and the evaluation results are described as follows.

\section{1) Material Expert Validation Data (chair of the SME group)}

One of the material validations was conducted by Slamet Kurniadi, SE, the chairperson of the Batik Sekar Alam Mandiri Batik group. Validation is done to obtain information that will be used to revise the material and improve the quality of application usage.

Table 1: Assessment of Material Quality Aspects by Material Experts

\begin{tabular}{|l|l|l|}
\hline No & Indikator & Skor \\
\hline 1 & The SME address information is correct & 5 \\
\hline 2 & Information on SMEs is correct & 5 \\
\hline 3 & GPS Information UKM is correct & 5 \\
\hline 4 & LBS SME information is correct & 4 \\
\hline 5 & Ease of Use of the application & 4 \\
\hline 6 & Easy search for GPS UKM & 4 \\
\hline 7 & Easy to find lbs UKM & 5 \\
\hline 8 & Category search facilities by category & 4 \\
\hline 9 & Application usage for UKM & 5 \\
\hline 10 & Use of applications for the public & 4 \\
\hline \multicolumn{2}{|l|}{ Total score } & $\mathbf{4 5}$ \\
\hline \multicolumn{2}{|l|}{ Average } & $\mathbf{4 , 5}$ \\
\hline
\end{tabular}

With a value that shows the total score of 45 and an average of 4.5 or $92 \%$, it shows the quality of the material for android and lbs based android applications is very good and worth using.

\section{2) Data of Media Expert Validation}

The validation of the media expert was carried out by Eko Budihartono.ST, M.Kom, lecturer in the Computer Engineering Study Program, Polytechnic. Validation is done to get information that will be used to revise the media and improve the quality of instructional media.

Table 2: Evaluation of Media Members in the Aspects of Programming

\begin{tabular}{|l|l|l|}
\hline No & Indicator & Score \\
\hline 1 & The SME address information is correct & $\mathbf{4}$ \\
\hline 2 & Information on SMEs is correct & $\mathbf{4}$ \\
\hline 3 & GPS Information UKM is correct & $\mathbf{5}$ \\
\hline 4 & GPS Information UKM is correct & $\mathbf{4}$ \\
\hline 5 & Ease of Use application & $\mathbf{4}$ \\
\hline 6 & Ease of finding GPS SMEs & $\mathbf{4}$ \\
\hline 7 & Ease of finding LBS SMEs & $\mathbf{3}$ \\
\hline 8 & Ease of search for SMEs by category & $\mathbf{4}$ \\
\hline 9 & Usefulness of application for SMEs & $\mathbf{4}$ \\
\hline \multicolumn{2}{|l|}{ Total score } & $\mathbf{3 6}$ \\
\hline Average & $\mathbf{4}$ \\
\hline
\end{tabular}


From the results of the questionnaire given to media experts consisting of programmers aspects questionnaire, received input for, a rather long loading time on the category menu, GPS location of all SMEs equipped, images of SME owners equipped, less large product images, searches cannot be by category, asked to be repaired.

Picture 3. Media Expert Rating on Display Aspects

\begin{tabular}{|l|l|l|}
\hline No & Indicator & Score \\
\hline 1 & Appropriate font selection & $\mathbf{3}$ \\
\hline 2 & The suitability of the writing color selection & $\mathbf{4}$ \\
\hline 3 & Appropriate font size selection & $\mathbf{4}$ \\
\hline 4 & Image clarity & $\mathbf{4}$ \\
\hline 5 & The accuracy of the background selection & $\mathbf{3}$ \\
\hline 6 & Readability of the text & $\mathbf{4}$ \\
\hline 7 & Matching colors on the button with the background & $\mathbf{4}$ \\
\hline 8 & Button consistency & $\mathbf{3}$ \\
\hline 9 & Display splash screen design & $\mathbf{4}$ \\
\hline 10 & Ease of Operation & $\mathbf{4}$ \\
\hline Total score & $\mathbf{3 7}$ \\
\hline Average & $\mathbf{3 , 7}$ \\
\hline
\end{tabular}

From the results of the questionnaire given to media experts consisting of programming aspects of the questionnaire and the display aspect showed good results, this is indicated by the results of the questionnaire media expert evaluation of the programming aspect showing a value of 3.6 or $80 \%$ and in terms of display aspects showing a score of 3.7 or $75 \%$.

c) Field Trial Data

Field trials are trials to measure the feasibility of whether or not the GPS and LBS-based UKM Android application was developed. The feasibility trial of the GPS and lbs based UKM android application is carried out at Griya Batik in Bandung village, on July 25 - July 29, 2019.

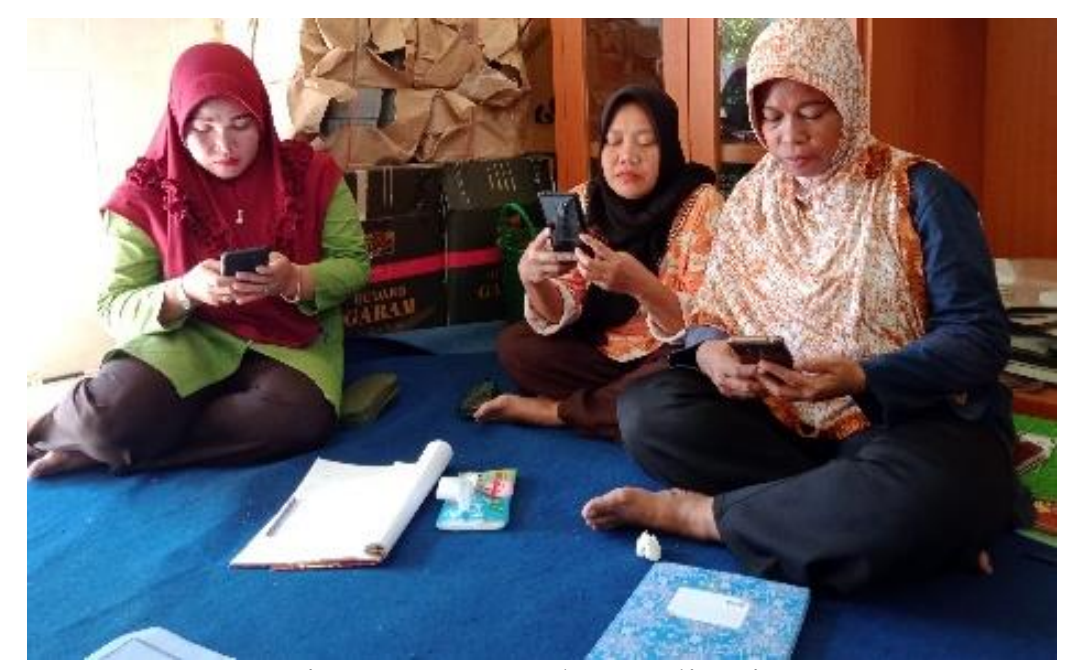

Picture 7: Test the application 


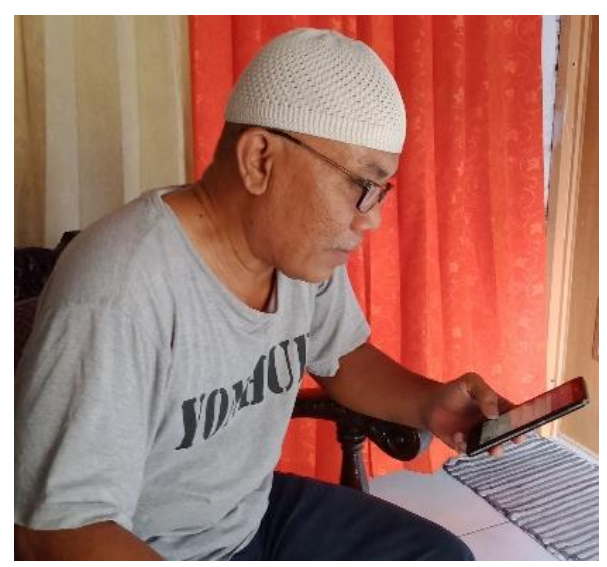

Picture 8: Test the application

\section{d. Final Product Review}

The development of a GPS and lbs based UKM android application program shows the enthusiasm of the community in using the application. This is because this program will introduce its UKM products and their UKM locations. Here are some overall views of the UKM Android application program based on GPS and LBS that have been completed.

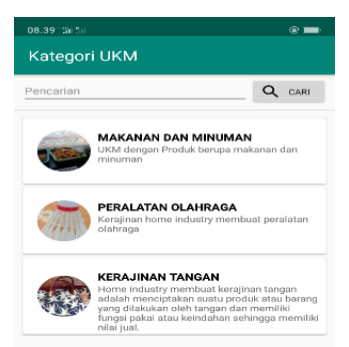

Picture 9: In the UKM menu

This menu consists of various menus, namely UKM, location, assistance and about. Here are the menus after we enter each of these menus.

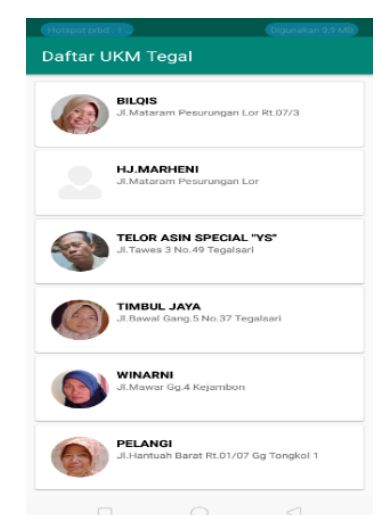

Picture 10: UKM food category 
List above the SMEs that are included in the food processing category, a photo of the owner appears, the name of the SME and its address, if you want more clearly click on the SME name.

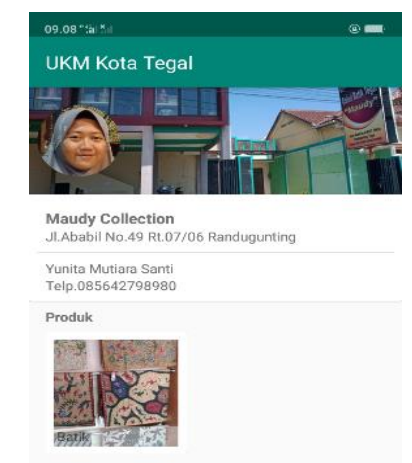

Picture 11: One of the UKM

Above are SMEs that are included in batik makers, photos of their owners, names of SMEs, products, telephone numbers and addresses appear.

\section{Conclusions and Recommendations}

From the research that has been done can be concluded,

1) GPS and LBS-based UKM Android application is successfully used to facilitate the public in finding UKM locations based on GPS and LBS maps

2) Implementation of the design of Android applications based on GPS and LBS Android makes it easier for the public to know the products produced by SMEs in the city of Tegal.

\section{Recommendation}

To complete the GPS and lbs based UKM android application, this application needs to be further developed to chat or send messages between the application user and the UKM.

\section{Acknowledgments}

Researchers express their gratitude to all those who have supported in completing this research in the form of time, motivation, and knowledge. Specially by Ministry of Research, Technology and Higher Education

(RISTEKDIKTI) Indonesia

\section{References}

[1] S. Masripah et al., "SWARM OPTIMIZATION UNTUK EVALUASI PENENTUAN," 2011.

[2] J. K. N. Jatmiko, "APLIKASI PROMOSI REMPEYEK KACANG DESA SROWOT BERBASIS ANDROID,” Syntax Lit., vol. 8, no. 5, p. 55, 2019. 
[3] EDDY PRAHASTA, Sistem Informasi Geografis Konsep-konsep Dasar. Bandung: INFORMATIKA, 2015.

[4] W. Hu, "A Location-Based Service Using Geometric Location Methods to Unite Mobile Users," vol. 14, no. 1, pp. 43-48, 2016.

[5] O. R. Erika, D. Kurniawan, and F. E. Febriansyah, “ Aplikasi Pencarian Letak Atm Berbasis Android Dengan Gis Di Kota Bandar Lampung ，" J. Komputasi, vol. 4, no. 1, pp. 27-35, 2016.

[6] S. Rabiah, "Penggunaan Metode Research and Development dalam Penelitian Bahasa Indonesia di Pergurtuan Tinggi," Univ. Muslim Indones., vol. 1, no. April 2015, pp. 1-7, 2015.

[7] A. Ruyani, I. Ansyori, P. Studi, P. Biologi, and U. Bengkulu, "PENDAHULUAN Pendidikan adalah suatu usaha sadar dan terencana untuk mewujudkan suasana belajar dan proses pembelajaran agar peserta didik dapat aktif mengembangkan potensinya . Sekolah merupakan lembaga formal yang berfungsi membantu khususnya orang tua d," vol. 1, no. 1, pp. 64-71, 2017.

[8] Fowler, Martin. 2004. UML Distilled:A Brief Guide to the Standard Object Modeling Language. Addison-Wesley Profesional. Boston

[9] R. Afyenni, "Perancangan Data Flow Diagram untuk Sistem Informasi Sekolah (Studi Kasus Pada SMA Pembangunan Laboratorium UNP)," Teknoif, vol. 2, no. 1, pp. 35-39, 2014.

[10] V. K. Bakti, A. C. Kusuma, J. Indriyanto, and P. H. Bersama, "ONLINE BAGI PELAKU INDUSTRI KECIL," no. x, pp. 1-6, 2018.

[11] I. N. Mardika, "Pengembangan Multimedia Dalam Pembelajaran Kosakata Bahasa Inggris Di SD," tripod. com/Multimedia. pdf [16 Juni 2012], no. 4, pp. 1-23, 2008.

[12] J. Indriyanto, I. Afriliana, and E. Budi Hartono, "Peningkatan kompetensi anggota HISPPIKota Tegal dalam penggunaan aplikasi berbasis android," J. Abdimas PHB, vol. 2, no. 1, pp. 13-17, 2019.

\footnotetext{
*Corresponding author.

E-mail address: dewajat@ gmail.com
} 